\title{
Creative Teaching Strategy to Reduce Bullying in Schools
}

\author{
Siti Irene Astuti Dwiningrum \\ Faculty of Science Education, Universitas Negeri Yogyakarta \\ Yogyakarta, Indonesia \\ https://orcid.org/0000-0001-6377-6074 \\ Norwaliza Abdul Wahab \\ Faculty of Human Development, Universiti Pendidikan Sultan Idris \\ Perak, Malaysia \\ https:/ / orcid.org/0000-0002-2713-1233 \\ Haryanto \\ Faculty of Science Education, Universitas Negeri Yogyakarta \\ Yogyakarta, Indonesia \\ https://orcid.org/0000-0002-8531-9891
}

\begin{abstract}
This paper aims to identify the teacher's strategy in creating and developing creative learning to purposely reduce bullying behaviour in schools. To assess this objective, a quantitative data approach was employed to explore the data on bullying behaviour to illustrate the teacher's strategy and creativity in reducing bullying. Previous findings revealed that bullying is prevalent during school hours (69\%), where the perpetrators consisted mainly of seniors (37\%). This study serves as an empirical picture of the strategies employed by creative teachers to reduce bullying in schools by building synergy at the school environment, class setting and individual level. As for the school environment, it is necessary to strengthen the links between learning elements and teachers' teaching style. However, there was a need to improve the learning abilities of teachers in classroom settings. At the individual level, effective collaboration between teachers and students needs to be strengthened by improving non-cognitive knowledge to take actions against bullying in schools. Also, it is essential to recognise findings, especially at the system level, to identify interventions and policies to ensure a secure and reliable learning environment for all students. This study also recommended the implementation of a training course for teachers to enhance their creative strategies in the classroom.
\end{abstract}

Keywords: bullying; creative teaching; elementary school; teaching strategies 


\section{Introduction}

Bullying encompasses a broad concept which can still potentially cause controversial arguments regarding its meaning, severity and its relationship with other constructions as it is a universal problem in schools (UNESCO, 2017). Bullying that occurs repetitively causes irreparable damage and is regarded as a social issue which is part of an aggressive manner (Erika, Pertiwi \& Seniwati, 2017). Afroz and Husain (2015) stated that there are many types of bullying such as mocking, hitting or intimidating others and spreading false information. It can be divided into two categories, namely direct bullying and indirect bullying. Direct bullying involves physical touch like beating, knocking, intimidating or any behaviour that inflicts injury to the victim. Meanwhile, indirect bullying through disrespectful remark affects the victim in psychological ways (Khalim, 2014). Based on previous literature, male students are more inclined towards direct bullying, whereas female students are towards indirect bullying (Boyes et al., 2014; Wang et al., 2009).

Based on studies conducted in multiple countries, bullying remains prevalent and has continued to affect people's lives. In Indonesia, research performed by the National Consortium Character Study in School Development indicated that almost all schools experience the bullying phenomenon (Firmansyah, 2014). This social fact was further supported based on the studies by Aryuni (2017), Dwiningrum (2019), Da Silva et al. (2019) and Chandra and Mulya (2009), which concluded that most of the students have been bullied. A study conducted in Malaysia, further revealed that the most common bullying acts in secondary schools are caused by teenagers with a high level of egocentrism. The study which involved 20 secondary school students demonstrated that their characteristics such as self-esteem, vengeance, enjoyment, authority and part of prejudice were the factors influencing bullying (Norshidah, 2014). Therefore, effective strategies are necessary to overcome bullying because the causal factors are very diverse, and the intensity continues to recur. Efforts to mitigate bullying cannot be postponed anymore due to its adverse impacts. However, survey techniques to evaluate bullying behaviour are not effectively practised in schools. For example, physical and verbal aggression is usually guarded using penalty responses.

Since bullying can occur in different manners, most teachers are not aware of it transpiring among students, hence, is difficult to apprehend dynamic precautions (Psunder, 2010; Veenstra et al., 2010). However, some school policies play a strategic role in reducing bullying. Effective ways to manage bullying at schools can be designed using creative learning processes. Having said that, creativity has not yet been fully utilised to overcome bullying in schools. Hence, this paper specifically explores techniques by which the teachers can incorporate creativity to reducing bullying at individual, class and school level to curb bullying among students. Based on the findings, interventions and policies can be identified and drafted to ensure a protected, safe and secure learning condition for all students. 


\section{Literature review}

\subsection{Bullying behaviour in schools}

Most of the available literature is more concerned with bullying in general and are unrelated to specific research findings (Rigby, 2017). Bullying is a type of social interaction which has an impact on schools and society. Hence, the behaviour of the perpetrators or victims together with other factors depend on the school environment. Bullying is a unique form of aggressive behaviour and is manifested in various patterns of relationships. Bully victims normally experience agitation, embarrassment and exasperation which consequently caused them to be timed, self-isolated from their friends, play truant, changed personality, sensitive, melancholy and suicidal. Among the effects of bullying on the victim include declining academic performance due to the loss of interest in learning, skipping classes and skipping school out of fear, self-blame together with the uncertainty about one's abilities and potential (Nor Junainah, Mohd Sobri \& Amelia, 2019). These effects have been identified to hold severe and lasting effects on the victim (Jenning et al., 2017; Hidalgo-Rasmussen et al., 2018).

Bullying is a worldwide issue regardless of gender, age, rank, race, culture or religion. Based on an international study conducted in 2015 by Musu-Gillette et al. (2017), bullying among students in some countries is at an alarming rate. The awareness against bullying helps students who face similar circumstances to come up with a resolution when they are bullied. Students with a significant level of bullying conduct are inclined not to bully, while students who are rarely bullied will, in general, be more domineering over other students (Saibon, Syed Abdullah \& Leong, 2017). Hence, teachers play a crucial role in facilitating appropriate interventions in school-related bullying cases.

\subsection{Creative Teaching Strategy}

The main idea of creative teaching is for the teachers to transform their classrooms into innovative learning environments to promote lifelong learning (Aleinikov, 1990). Creative teaching strategy requires teachers to make teaching and learning fun by using a practical and imaginative approach in the classroom (Cremin, Burnard \& Craft, 2006). Creative teaching is a strategy for teachers to recognise students' abilities to further empower and provide chances to their turn of events. Meanwhile, this strategy is also described using a visionary approach to make teaching and learning more enjoyable and productive.

To practice creative teaching, the teacher must possess some principles. Teachers must be able to explore their identity and potential to develop the capacity and sensitivity to think creatively. This, in turn, can help them to become creative individuals. In this context, teachers should also be able to integrate local knowledge to build creativity in conducting learning in the classroom. Whereby creative thinking and critical thinking could enhance and complement each other. Creative teaching leads to creative learning is not only an essential factor in overcoming the complexities of social change but also acts as a catalyst in creating a rapidly emerging global knowledge society. Hence, creative learning should be the primary focus area in all disciplines and at all grade levels. In addition, 
educators do also need to understand the factors driving creative learning (Watts \& Blessinger, 2017).

In general, an essential educational goal is to develop social creativity (Craft, 2005). Researchers have explained that education is not only limited to the study of relevant theory but also provides many practical suggestions for schoolteachers. However, practical activities in the classroom that focus on fostering creativity does not necessarily yield the expected results, which is to reduce bullying among students. Creative learning in the perspective of constructivism theory can be related to the principles of constructivism which can be illustrated as 1) knowledge is developed by students, exclusively and socially, 2) knowledge cannot be conveyed from teacher to student, 3) students construct actively and continuously, and 4) teachers help provide circumstances in line with the goal for the development of students. Constructive learning occurs when students continually check for new information that is contrary to the old rules and revise those rules if they are no longer appropriate (Danarjati, Murtiadi \& Ekawati, 2014). Creative learning process requires 1) democratic learning environment and atmosphere, 2) interactive student-centred learning activities and 3) educators who encourage students to learn on one's own and be accountable for their learning activities.

In demonstrating creative learning, firstly, the teacher must model and provide verbal remarks about their actions along with an explanation to it. Secondly, students must attempt to mirror what the teacher is doing. In the third phase, the teacher must progressively reduce intervention once the student has mastered the skill. Fourthly, the teacher and students repeatedly take the roles in turns as children need to be regularly confronted with concepts so that their spontaneous ideas become more accurate (Khodijah, 2016). Besides that, teachers should be aware of the importance of guiding to building a conducive atmosphere that reduces bullying behaviour in the classroom. Hence, classroom settings should be in the form of cooperative learning between groups of students with different abilities. In a conducive environment, students will be able to interact in performing difficult tasks, bring up each other's practical problem-solving strategies within the closest or proximal development area and emphasise their role as students to take responsibility for their learning.

Creative teaching strategy or creative pedagogy emphasises on the role of teachers and students. For instance, creative teaching strategy is practised by forming new ideas, new approaches and imagination leading to the inventive teaching method or creative pedagogy. Teachers act as guidance to create dynamic and adaptable activities in the classroom (Dineen \& Niu, 2008). Consequently, the implementation of creative teaching strategy should be incorporated into a bullying intervention program to boost student awareness regarding bullying behaviour among students. 


\section{Methodology}

This study employed two approaches, quantitative and qualitative. Quantitative data approach was aimed at exploring data regarding bullying behaviour in schools. A survey was used to describe the profile of bullying in schools, i) bullying setting and ii) bullying perpetrators. The survey questionnaires were distributed among 970 students from 11 secondary schools in Jakarta using stratified sampling. The data collected were analysed using percentage calculations to describe the profile of bullying in schools.

In contrast, qualitative data approach was intended to illustrate the teacher's strategy and creativity in reducing bullying in schools. The teachers were recruited using purposive sampling. A total of 55 teachers from 11 schools were selected and were interviewed. The interview was audio recorded for 30 minutes and transcribed to verbatim. Observations in schools were also conducted using the observation checklists to describe the social processes that occurred in these schools to overcome bullying. Once the interview and observation were completed, the data were analysed to identify the themes. Teachers' preintervention practices were identified to develop student and school resilience by designing creative learning programs at three levels, i) school level, ii) classroom level and iii) individual level.

This study aims to explore students' bullying behaviour and teachers' creative learning processes to reduce bullying behaviour in school. Through the outcome of this study, we aim to answer these questions. Firstly, when does bullying occur among students from secondary schools in Jakarta? Secondly, who are the perpetrators in bullying? Thirdly, how will the teachers implement the creative teaching strategies to reduce bullying at the school, class, and individual levels?

\section{Results and Discussion}

\subsection{Bullying behaviour in school}

Based on Figure 1, it can be concluded that bullying mostly occurs within the school environment, especially during school hours (69\%) and break time $(23 \%)$. Some cases were reported to have occurred before school hours (8\%), while none after school. A study done by UNICEF (2018) stated that the findings coincided with the exposure of victims during school hours especially at the school cafeteria and restrooms, the leading spots for bullying. 


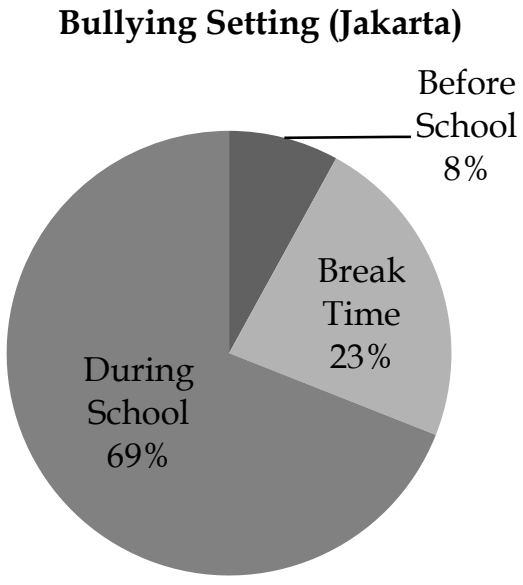

Figure 1: Bullying setting

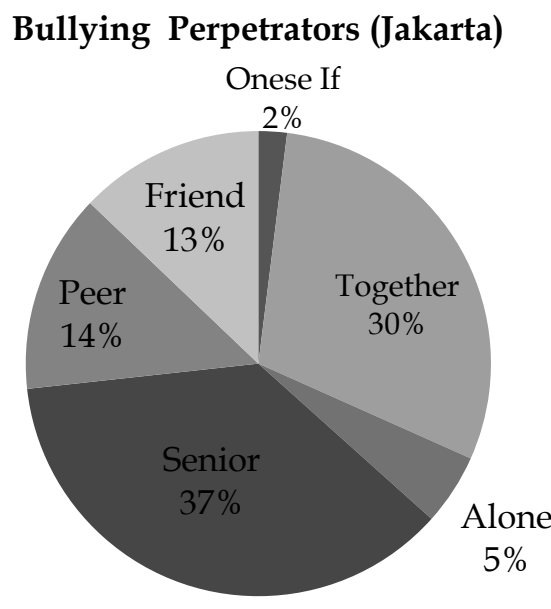

Figure 2: Bullying perpetrators

Based on Figure 2, the bullying perpetrators among high school students in Jakarta consisting of seniors $(37 \%)$, together $(30 \%)$, classmates $(14 \%)$ and their friends $(13 \%)$. This figure is further supported by the statements of high school students who claimed that most bullying cases occurred together and by seniors. This phenomenon revealed that the bullies dare to bully the victims when they are together during break time. Break time provides an excellent opportunity to oppress the victims as there would be no teacher supervision. Meanwhile, victims have also reported that bullying occurred in the classroom when there were no teachers (35.9\%) or during on-going lessons (30.2\%). Dwiningrum (2019) also concluded that as many as $48.2 \%$ of the students claimed to have been victimised, while $45.1 \%$ of the students had been perpetrators. Similar trends were also observed in a study conducted in Malaysia on bullying, which is becoming a severe issue (Wan-Salwina et al., 2014). In Canada, it was reported that 25.2\% of the students were also victims of school bullying (Sampasa-Kanyinga, 2014). These considerable extents demonstrate that school bullying is still prevalent among middle and high school students.

According to Dwiningrum (2019), bullying behaviour in the school environment cannot be eliminated naturally. Perpetrators tend to bully the victims mostly during break time since they will be far from the supervision of teachers. Hence, schools must strengthen the social functions, especially among the students to create bond among them. In brief, bullying persists due to social reproduction. Although bullying has been proved to be prevalent in school environments, most teachers still are incapable of dealing with it. Based on the literature, programs implemented to mitigate bullying in schools is not easy because the personality of each student is not the same as assessing the bullying behaviour. Such differences in personalities remain as one of the components of continuing bullying behaviour in schools. Besides that, based on the interviews with teachers in high schools, there were several obstacles to mitigating bullying in schools:
a. Diversified knowledge about bullying.
b. Student ignorance in responding to bullying.
c. Low awareness about the impact of bullying. 
d. Differences in economic, racial, religious, social, cultural and economic backgrounds among students.

e. Limited time to provide knowledge in classroom learning.

f. Discriminatory attitude between students and teachers.

However, according to teachers, bullying often occurs in the classroom (Nouran, 2015). Schools continuously try to overcome bullying by employing a variety of strategies with the school policies. These strategies are critical to consider because the impact of bullying is very complex. Programs to stop bullying are moral movements that must be fought by schools. The dire efforts to stop bullying is focused on the overwhelmed suffering of victims by repeated bullying. Juvonen and Graham (2014) also added that victims of bullying experience more serious alteration issues compared to victims of different types of peer hostility. Since bullying is a more destructive and complex element of aggressive behaviour, specific interventions are needed (Ttofi et al., 2011). Hence, schools must deal with bullying more diligently and seriously to achieve optimal results. This study concluded that the schools are trying to design comprehensive techniques in combatting bullying on school grounds. Based on the qualitative data analysis, school policies in reducing bullying were carried out at three levels, i) school level, ii) classroom level and iii) individual level (Olweus, 1993). This strategy is intended as the main segments fundamental to the implementation of an antibullying program (Olweus \& Alsaker, 1991).

\subsection{At the school level}

According to Alter and Hadon (2017), classroom rules are conveyed by teachers to portray satisfactory and inadmissible conduct among the students. Based on the interviews with teachers, classroom rules against violence are conveyed through, i) written agreements with students and making it a school effort to create a healthy and friendly environment, ii) moral messages composed by schools were displayed in posters and banners at several strategic places in the school environment for students to read; iii) policies created to strengthen character education integrated into various school programs such as anti-bullying programs; iv) the schools cooperated with parents to monitor children's behaviour at home. According to Jimenez-Barbero et al. (2016), anti-bullying programs have significantly reduced the frequency of bullying cases and victimisation among students.

\subsection{At the classroom level}

Teachers deal with bullying problems in classrooms by associating it with the learning process. Based on the description in Table 1, it can be interpreted that to develop creativity, teachers need appropriate and comprehensive knowledge in overcoming various problems of bullying in schools. In order to create creative learning based on the perspectives of constructivist theories, the teacher's role should optimise five elements of learning including a) activating knowledge, b) acquiring knowledge by learning as a whole first, then paying attention to the details, c) understanding knowledge, i.e. constructing a temporary concept (hypothesis), sharing with others to get a response (validation) and based on that response, the idea is revised and developed, d) applying knowledge, and e) 
reflecting on the knowledge development strategy. Table 1 illustrates that each teacher apprehends different ways of dealing with bullying among students.

Table 1. Elements and activities of teachers in the teaching process

\begin{tabular}{|c|c|}
\hline Elements of learning & Teacher activities \\
\hline Activating knowledge & $\begin{array}{l}\text { Improve the literacy of the Koran by reading } \\
\text { intensively at the beginning of class entry/end } \\
\text { of learning in school. } \\
\text { - Leading prayers in class. }\end{array}$ \\
\hline $\begin{array}{l}\text { Acquiring knowledge by } \\
\text { learning, then paying } \\
\text { attention to the details }\end{array}$ & $\begin{array}{l}\text { - Acquire the experience and impact of bullying } \\
\text { in schools. } \\
\text { - Integrating character values in learning in } \\
\text { schools with structured activities. }\end{array}$ \\
\hline $\begin{array}{l}\text { Acquiring knowledge by } \\
\text { learning, then paying } \\
\text { attention to the details }\end{array}$ & $\begin{array}{l}\text { - Organise certain activities/programs organised } \\
\text { by students between classes to build } \\
\text { togetherness between students. } \\
\text { - Coordinate with parents to supervise children } \\
\text { at home. } \\
\text { - Warn and punish students who commit acts of } \\
\text { violence in class/school gradually. } \\
\text { - Develop topics for specific material and } \\
\text { discussion in class to build awareness of } \\
\text { mutual respect and respect between } \\
\text { students/teachers. }\end{array}$ \\
\hline Applying knowledge & $\begin{array}{l}\text { - Organise competitions between classes and } \\
\text { schools in various fields of learning, sports, arts } \\
\text { and music to develop students' creativity and } \\
\text { reduce conflicts between students. } \\
\text { - Develop group dynamics in the classroom for } \\
\text { learning and creative work through social and } \\
\text { entrepreneurial activities. }\end{array}$ \\
\hline $\begin{array}{l}\text { Reflecting on the } \\
\text { knowledge development } \\
\text { strategy }\end{array}$ & $\begin{array}{l}\text { - Conduct out-bound activities to strengthen } \\
\text { leadership and capacity building. } \\
\text { - Conduct social activities that build a sense of } \\
\text { social solidarity and social care. }\end{array}$ \\
\hline
\end{tabular}

In addition, the ability to be creative is deemed as an important aspect to reduce bullying (Komalasari, 2011). Teacher's creative learning in the class consists of creative teaching imaginative approach to develop creative thinking behaviour, as stated in Table 2. 
Table 2. The teacher's creative learning in class

\begin{tabular}{|c|c|}
\hline $\begin{array}{l}\text { Creative teaching imaginative } \\
\text { approach }\end{array}$ & $\begin{array}{c}\text { Teaching for creativity to develop creative } \\
\text { thinking or behaviour. }\end{array}$ \\
\hline $\begin{array}{l}\text { 1. Teach students how to respond to } \\
\text { challenges } \\
\text { 2. Teach students to develop ideas in } \\
\text { overcoming the problem of } \\
\text { bullying in schools using empirical } \\
\text { data. } \\
\text { 3. Encourage students to study } \\
\text { enthusiastically. } \\
\text { 4. Practising openness in } \\
\text { communication. } \\
\text { 5. Teach students about social } \\
\text { sensitivity in people's lives. } \\
\text { 6. Oversee personal growth with a } \\
\text { humanist approach. }\end{array}$ & $\begin{array}{l}\text { 1. Introduce thinking and creative } \\
\text { methods by changing the mindset. } \\
\text { 2. Getting used to doing tasks } \\
\text { effectively and creatively. } \\
\text { 3. Getting used to organising } \\
\text { classrooms to be safe and } \\
\text { comfortable for students to learn. } \\
\text { 4. Develop a culture of reading and } \\
\text { learning. } \\
\text { 5. Encourage students to produce } \\
\text { creative products. }\end{array}$ \\
\hline
\end{tabular}

Based on the data above, it can be interpreted that the ability of teachers in creative teaching can be developed if they have sufficient knowledge about creative teaching imaginative approach. According to the NACCCE Report (1999), the importance of developing the aspects of creativity in teaching is considered as their capability in overcoming social problems. The knowledge gained by students through fun and meaningful learning processes will be a fundamental basis for students for personal character or behaviour.

\subsection{At the individual level}

Bullying behaviour affects the physical and mental health of victimised students. Therefore, efforts to reduce bullying behaviour requires a good relationship between teacher and teacher, teacher and students, and student and students, as shown in Table 3.

Table 3. Relationship pattern and activities to deal with bullying in schools

\begin{tabular}{|l|l|}
\hline $\begin{array}{l}\text { Relationship } \\
\text { pattern }\end{array}$ & \multicolumn{1}{c|}{ Form of activity } \\
\hline Teacher with teacher & $\begin{array}{l}\text { - Sharing mutual experiences among fellow teachers in their } \\
\text { efforts to deal with children who tend to bully in class. } \\
\text { Sharing mutual variety of information on ways of teaching } \\
\text { that encourage students to learn creatively. }\end{array}$ \\
\hline $\begin{array}{l}\text { Teacher with } \\
\text { students }\end{array}$ & $\begin{array}{l}\text { - Play a film that has a moral message about bullying. } \\
\text { in groups on the impacts of bullying and solutions to overcome } \\
\text { bullying. }\end{array}$ \\
\hline $\begin{array}{l}\text { Students with } \\
\text { students }\end{array}$ & $\begin{array}{l}\text { - Create a "Peer Counselling" activity for students, so that } \\
\text { they could have the opportunity to talk to their peers freely } \\
\text { when experiencing bullying problems. }\end{array}$ \\
$\begin{array}{l}-\quad \text { Create an "anti-bully" group formed by students as } \\
\text { ambassadors of peace at school. }\end{array}$ \\
\hline
\end{tabular}


According to Table 3, social synergy must be built to combat bullying by building a safe and comfortable school for students. Although all schools are ready to comply with new techniques, creating a safe and enjoyable school culture is not an easy task. Having said that, an appropriate approach to combat bullying is to focus on developing non-cognitive skills for students to resist bullying behaviour. By fostering proactive factors such as resilience and other non-cognitive skills, bullying can be reduced along with its harmful effects on students. When these skills are instilled in students, they are provided with mental self-defence to safeguard themselves from being bullied or from becoming the perpetrators.

\section{Conclusion, Implications and Recommendations}

Creative learning strategy should be acquired by teachers, especially to curb bullying among students. This study concluded that:

- At the school level, there is a need to strengthen knowledge and it must be constructed expertly. The problem of bullying must be recognised as an action that must be addressed together by enhancing awareness in all elements of learning. A comprehensive approach for a positive school environment which emphasises student wellbeing and reinforces a norm of inclusiveness and diversity is crucial in preventing bullying.

- At the classroom level, teachers are expected to be able to apply a variety of learning processes to make students happy and comfortable. With a conducive learning environment, there would be no reasons for students to bully. With creative learning, teachers could build a conducive and comfortable learning atmosphere for students in school.

- At the individual level, it requires social relationships that are built through various social activities by strengthening aspects of non-cognitive abilities to reduce bullying in schools.

Teachers can acquire creative teaching strategy by attending courses and training programs. During this Covid-19 pandemic, teachers can opt to join online professional development courses available on the internet on how to secure a positive school climate. This study also implies that school policies which are designed to reduce bullying need to be balanced in creating lessons with cognitive knowledge and non-cognitive expertise in the learning process. This recommendation offers a guideline for a new framework and further research.

\section{Acknowledgement}

This paper presented here is collaboration research activities supported by Kementerian Riset, Teknologi, dan Pendidikan Tinggi Republik Indonesia who have provided research development funds 2019 following the contract number: 73 / Research / PP / UN34.21 / 2019 and part of the matching grant between Universitas Negeri Yogjakarta (UNY) and Research Management and Research Centre (RMIC), Universiti Pendidikan Sultan Idris (UPSI) Research Code 20190240-107-01. Special thanks to for all researchers for their contributions. 


\section{References}

Afroz, J. M. S., \& Husaain, S. (2015). Bullying in elementary schools: Its causes and effects on students. Journal of Education and Practise, 6(19), 43-56.

Aleinikov, A. G. (1990). Creative pedagogy and creative meta pedagogy. Progress in Education, 65(12), 274-80.

Alter, P., \& Haydon, T. (2017). Characteristics of effective classroom rules: a review of the literature. Teacher Education and Special Education. The Journal of the Teacher Education, 40(1). https://doi.org/10.1177/0888406417700962

Aryuni, M. (2017). Strategi pencegahan bullying melalui program "sekolah care" bagi fasilitator teman sebaya. [Bullying prevention strategies through the "school of care" program for peer facilitators]. Asian Journal of Environment, History and Heritage, 1(1), 211- 222.

Boyes, M. E., Bowes, L., Cluver L. D., Ward, C. L., \& Badcock, N. A. (2014). Bullying victimisation, internalising symptoms, and conduct problems in South African children and adolescents: A longitudinal investigation. Journal of Abnormal Child Psychology, 42(8), 1313-1324. https:// doi.org/10.1007/s10802-014-9888-3

Bush, M. D. (2011). A quantitative investigation of teachers' responses to bullying. (Doctoral dissertation, Indiana University of Pennsylvania).

Chandra, F. O., \& Mulya, T. W. (2009). Perilaku pembulian pada siswa SMA di Surabaya. [Bullying behavior of Surabaya High School Students]. Anima, Indonesian Psychological Journal, 24(4), 384-264.

Craft, A. (2005). Creativity in schools: Tensions and dilemmas. London: Routledge. https://doi.org/10.4324/9780203357965

Cremin, T., Burnard, P., \& Craft, A. (2006). Pedagogies of possibility thinking in the early years. International Journal of Thinking Skills and Creativity, 1(2), 108-19. https:// doi.org/10.1016/j.tsc.2006.07.001

Da Silva, M. A, Gonzalez, J. C., Person, L. G., \& Silvia S. S. (2019). Bidirectional association between bullying perpetration and internalising problems among youth. Journal of Adolescent Health, 66(3), 315-322. https://doi.org/10.1016/j.jadohealth.2019.09.022

Danarjati, D. P., Murtiadi, A., \& Ekawati, A. R. (2014). Psikologi pendidikan. [Educational psychology]. Graha Ilmu: Yogyakarta

Desmita. (2010). Perkembangan peserta didik. [Student participant development]. Remaja Rosda Karya: Bandung.

Dineen, R., \& Niu, W. (2008). The effectiveness of Western creative teaching methods in China: An action research project. Psychology of Aesthetics, Creativity, and the Arts, 2(1), 42-52. https:// doi. org/10.1037/1931-3896.2.1.42

Dwiningrum. (2019), S.I.A. Pengembangan resiliensi sekolah untuk mengatasi bullying berbasis kearifan lokal. [Development of school resilience to address local affective bullying]. Lembaga Peneliti dan dan Pengabdian Masyarakat UNY: Yogyakarta.

Erika, K. A., Pertiwi, D. A., \& Seniwati, S. (2017). Bullying behaviour of adolescent based on gender, gang and family. Jurnal Ners, 12(1), 126-132.

Firmansyah, T. (2014). Aduan Bullying Tertinggi. [Highest Bullying Complaint] Republika, pp. 1.

Hidalgo-Rasmussen, C. A., Ramírez-López, G., Rajmil, L., Skalicky, A., \& Martín, A. H. (2018). Bullying and health-related quality of life in children and adolescent Mexican students. Ciencia and Saude Coletiva, 23(7), 2433-2441. https:// doi.org/10.1590/1413-81232018237.16392016

Jennings, W. G., Song, H., Kim, J., Fenimore, D. M., \& Piquero, A. R. (2017). An examination of bullying and physical health problems in adolescence among 
South Korean youth. Journal of Child and Family Studies, 1-12. https://doi.org/10.1007/s10826-017-0885-3

Jimenez-Barbero, J., Ruiz-Hernandez, J., Llor-Zaragoza, L., PirezGarcia, M., \& LlorEsteban., B. (2016). Effectiveness of anti-bullying school programs: A metaanalysis. Children and Youth Services Review, 61, 65-175. https://doi.org/10.1016/j.childyouth.2015.12.015

Juvonen, J., \& Graham, S. (2014). Bullying in schools: the power of bullies and plight of victims. Annual Review of Psychology, 65, 159-185.

Khalim, Z. (2014). Pengurusan disiplin pelajar sekolah. [Managing student discipline]. Universiti Kebangsaan Malaysia: Bangi.

Khodijah, N. (2016). Psikologi pendidikan. [Educational psychology]. Raja Grafindo: Jakarta

Komalasari, K. (2011). Pembelajaran kontekstual, konsep dan aplikasi, kualitatif, dan $R \mathcal{E} D$. [Contextual learning, concepts and applications, qualitative, and R\&D]. Refika Aditama: Bandung.

Musu-Gillette, L., Zhang, A., Wang, K., Zhang, J., \& Oudekerk, B. A. (2017). Indicators of school crime and safety: 2016 (NCES 2017-064/NCJ 250650). National Center for Education Statistics, U.S. Department of Education, and Bureau of Justice Statistics, Office of Justice Programs, U.S. Department of Justice: Washington DC. Retrieved from https://nces.ed.gov/pubs2017/2017064.pdf

National Advisory Committee on Creative and Cultural Education [NCCCE]. (1999). All our futures: Creativity, culture and education. DFEE: London.

Nor, J. M. I., Mohd, S. I., \& Amelia, M. N. (2019). Masalah buli dalam kalangan murid: Apakah kata guru? [Bullying problems among students: what do teachers say?]. Jurnal Perspektif, 11(2), 1-14.

Norelawaty, S., Zuria, M., \& Noran-Fauziah, Y. (2008). Tingkah laku buli dalam kalangan pelajar perempuan sekolah rendah. [Bullying behavior among elementary school students]. Jurnal PSIMA, 20(1), 1-20.

Norshidah, M. S. (2014). Bullying among secondary school students in Malaysia: A case study. International Education Studies, 7(13), 184-191. https://doi.org/10.5539/ies.v7n13p184

Nouran, H. F. (2015). Teachers' knowledge about bullying in elementary schools in Saudi Arabia. Master's project. The State University of New York at Fredonia.

Olweus, D. (1993). Bullying in schools: what we know and what we can do. Blackwell Publishers: Oxford.

Olweus, D., \& Alsaker, F. D. (1991). Assessing change in a cohort longitudinal study with hierarchical data. Problems and methods in longitudinal research. Cambridge University Press: New York.

Psunder, M. (2010). The identification of teasing among students as an indispensable step towards reducing verbal aggression in schools. Educational Studies, 36(2), 217-228. https:// doi.org/10.1080/03055690903162192

Rigby, K. (2017). Exploring the gaps between teachers' beliefs about bullying and research-based knowledge. International Journal of School E Educational Psychology, 6(3), 165-175. https://doi.org/10.1080/21683603.2017.1314835

Saibon, J., Syed Abdullah, S. M., \& Leong, A. C. H. (2017). Effectiveness of creative pedagogy in enhancing the knowledge and awareness on bullying amongst secondary school students. Advances in Social Science, Education and Humanities Research, 133, 160-165.

Sampasa-Kanyinga, H., Roumeliotis, P., \& Xu, H. (2014). Associations between Cyberbullying and School Bullying Victimization and Suicidal Ideation, Plans and Attempts among Canadian Schoolchildren. PLoS ONE, 9(7), e102145. https://doi.org/10.1371/journal.pone.0102145 
Ttofi, M. M., Farrington, D. P., Losel, F., \& Loeber, R. (2011). Do the victims of school bullies tend to become depressed later in life? A systematic review and metaanalysis of longitudinal studies. Journal of Aggression, Conflict and Peace Research, 3(2), 63-73. https://doi.org/10.1108/17596591111132873

United Nations Children's Fund [UNICEF]. (2018). Children4Change survey 2018: Bullying experiences amongst children and adolescent in Malaysia. Retrieved from https://children4change.unicef.my/wpcontent/uploads/WCD-C4C-2018

United Nations Educational, Scientific and Cultural Organization [UNESCO]. (2017). School violence and bullying: Global status report. Paris, France. Retrieved from http:// unesdoc.unesco.org/images/0024/002469/246 970e.pdf

Veenstra, R., Lindenberg, S., Munniksma, A., \& Dijkstra, J. K. (2010). The complex relation between bullying, victimisation, acceptance, and rejection: Giving special attention to status, affection, and sex differences. Child Development, 81(2), 480-486. https://doi.org/10.1111/j.1467-8624.2009.01411

Wang, J., Iannotti, R. J., \& Nansel, T. R. (2009). School bullying among adolescents in the United States: Physical, verbal, relational, and cyber. Journal of Adolescent Health, 45(4), 368-375. https://doi.org/10.1016\%2Fj.jadohealth.2009.03.02

Wan-Salwina, W. I., Nik, R. N. J., Hatta, S., Marhani, M., \& Shamsul, A. S. (2014). Why do young adolescents bully? Experience in Malaysian schools. Comprehensive Psychiatry, 55, 114-120. https://doi.org/10.1016/j.comppsych.2013.05.002

Watts, S. L., \& Blessinger, P. (2017). Creative Learning in Higher Education: Routledge. 


\section{Appendix 1}

\section{Creative Teaching Strategy to Reduce Bullying in Schools Instruments}

Please indicate your level of agreement with the statement listed below:

$1=$ Strongly agree

$2=$ Agree

$3=$ Neutral

$4=$ Disagree

$5=$ Strongly Disagree

\begin{tabular}{|c|c|c|c|c|c|c|}
\hline No & Items & $\mathbf{1}$ & 2 & 3 & 4 & 5 \\
\hline 1 & I experienced bullying at school & & & & & \\
\hline 2 & $\begin{array}{l}\text { I experienced bullying in the } \\
\text { community }\end{array}$ & & & & & \\
\hline 3 & I experienced bullying at home & & & & & \\
\hline 4 & $\begin{array}{l}\text { Bullying at school occurs before } \\
\text { lessons begin }\end{array}$ & & & & & \\
\hline 5 & Bullying occurs during lessons & & & & & \\
\hline 6 & Bullying occurs during school breaks & & & & & \\
\hline 7 & Bullying happens after school & & & & & \\
\hline 8 & Bullying happens repeatedly & & & & & \\
\hline 9 & Bullying often happens in my school & & & & & \\
\hline 10 & Bullying often happens in my class & & & & & \\
\hline 11 & I do bully & & & & & \\
\hline 12 & My friend also bully people & & & & & \\
\hline 13 & $\begin{array}{l}\text { Bullying is done by fellow } \\
\text { classmates }\end{array}$ & & & & & \\
\hline 14 & Bullying is done by seniors & & & & & \\
\hline 15 & Bullying is done alone & & & & & \\
\hline 16 & Bullying is done together & & & & & \\
\hline 17 & I became a victim of bullying & & & & & \\
\hline 18 & My friend is also a victim of bullying & & & & & \\
\hline 19 & $\begin{array}{l}\text { Bullying is done by friends who are } \\
\text { more powerful }\end{array}$ & & & & & \\
\hline 20 & $\begin{array}{l}\text { Bullying occurs because the victim is } \\
\text { weak }\end{array}$ & & & & & \\
\hline 21 & $\begin{array}{l}\text { Bullying occurs because of inferiority } \\
\text { complex }\end{array}$ & & & & & \\
\hline 22 & $\begin{array}{l}\text { Bullying occurs because victims are } \\
\text { physically different }\end{array}$ & & & & & \\
\hline
\end{tabular}




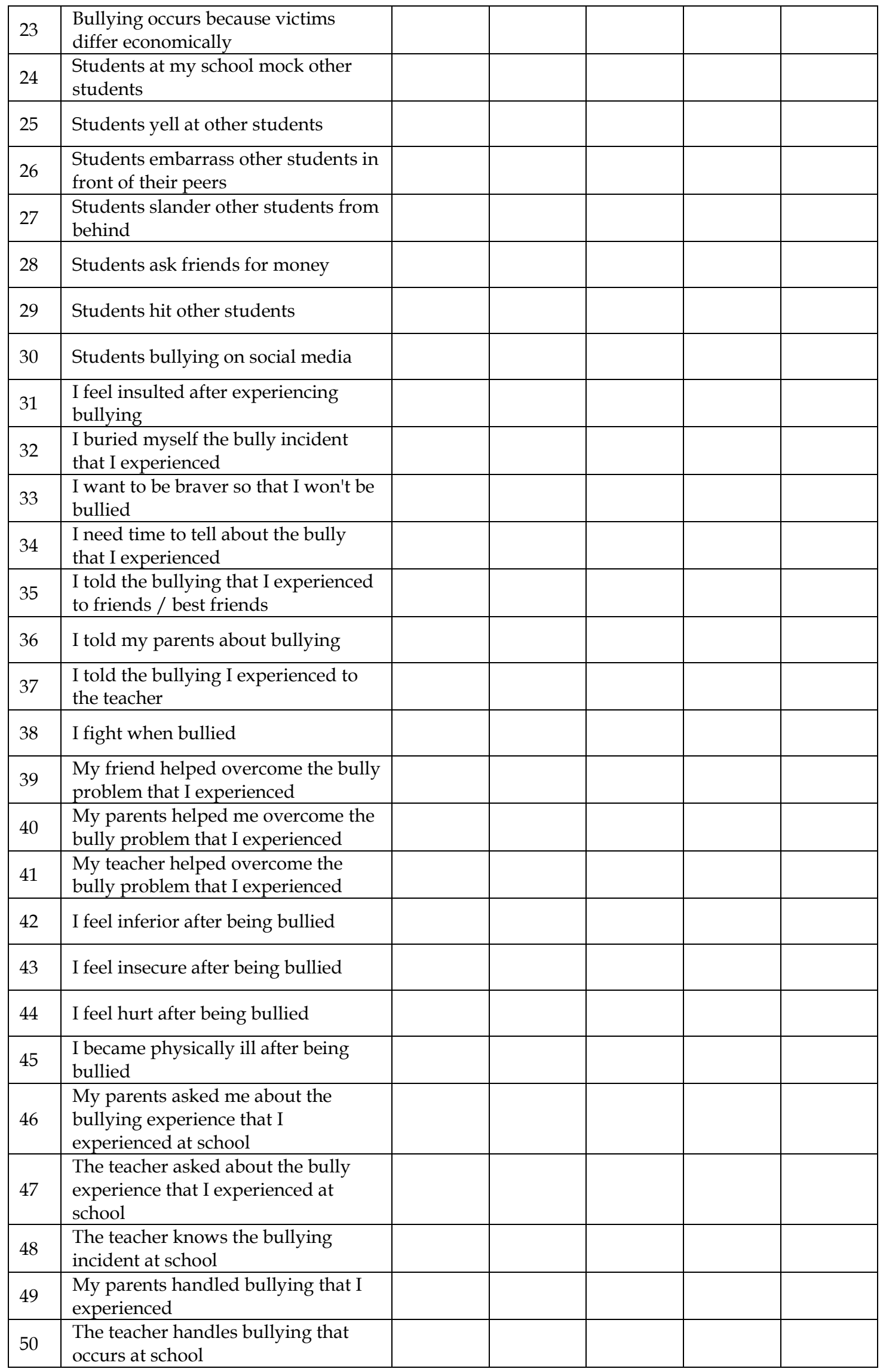

